\title{
HAMBATAN KOMUNIKASI YANG DIRASAKAN PETANI SELAMA PEMBINAAN PETANI PADI (ORIZA SATIVA) DI DESA OESAO KABUPATEN KUPANG
}

\author{
Bulkis \\ FMIPA-Universitas Terbuka \\ e-mail: bulkis@ecampus.ut.ac.id
}

\begin{abstract}
The objective of the research was to describe the factor of individual characteristic and communication activity, the communication barriers of rice farmers the analysing the relation between the factor of farmers individual characteristic and the communication barriers that felt by rice farmer in theOesao villageKupang district. Quantitative approach was chosen by the researcher because of the descriptions the explained the relation among variables in depth by the unit of analysis was rice farmer so that it can be show the clear relation between variables. There were two variables of research that observed, they were characteristic of farmer (X1), farmer communication activity (X2), communication barrier between agricultural extension and farmer $(Y)$. The result of the research showed that 1) communication barriers most felt by the farmers were caringand solidarityfactor, then prejudice factor, difference of expectation and difference of needs.2) the experience of farmer was very significantly related with prejudice factor barrier, cared, solidarity then has significantly related with communication barrier of difference of needs. 3) Characteristic of farmer cosmopolite has significantly related negative with barriers factor of communication at prejudice, difference of needs, cared, and solidarity. Characteristic of the extent of farmer knowledge has significantly related negative with all of barriers factor of communication that felt by the rice farmer at Oesao villageKupang district. Communication activity was generally significant and very real with barriers of communication that felt by rice farmer at Oesao Kab. Kupang.
\end{abstract}

Keywords: agricultural extension, communication barrier, rice farmer

\begin{abstract}
ABSTRAK
Penelitian ini bertujuan untuk mendeskripsikan faktor karakteristik individu dan aktivitas komunikasi, hambatan-hambatan komunikasi yang ada pada petani padiserta menganalisis hubungan antara faktor karakteristik individu petani dan aktivitas komunikasi dengan hambatan komunikasi yang dirasakan petani padi di Desa Oesao Kab. Kupang. Pendekatan kuantitatif dipilih oleh peneliti karena melihat deskripsi serta menjelaskan hubungan antar variabel secara mendalam, dengan unit analisis adalah petani tanaman padi sehingga dapat memperlihatkan hubungan yang jelas antar variabel. Terdapat dua variabel penelitian yang diamati yaitu karakteristik petani (X1), aktivitas komunikasi petani(X2), hambatan komunikasi antara penyuluh dan petani(Y). Hasil penelitian yang diperoleh bahwa:1) Hambatan komunikasi yang paling dirasakan petani adalah pada faktor perhatian dan
\end{abstract}


keakraban, disusul dengan faktor prasangka, perbedaan harapan dan perbedaan kebutuhan. 2) Pengalaman petani berhubungan sangat nyata pada faktor hambatan prasangka, perhatian dan keakraban serta berhubungan nyata dengan hambatan komunikasi faktor perbedaan kebutuhan. 3) Karakteristik kekosmopolitan petani berhubungan sangat nyata negatif dengan faktor hambatan-hambatan komunikasi pada prasangka, perbedaan kebutuhan, perhatian dan keakraban. Karakteristik tingkat pengetahuan petani berhubungan sangat nyata negatif dengan seluruh faktor hambatan-hambatan komunikasi yang dirasakan petani padi di Desa Oesao Kab. Kupang. Aktivitas komunikasi secara umum berhubungan nyata dan sangat nyata dengan hambatan-hambatan komunikasi yang dirasakan petani padi di Desa Oesao Kab. Kupang.

Kata kunci: hambatan komunikasi, penyuluh, petani padi

Indonesia sebagai negara agraris yang sebagian penduduknya adalah petani dan Indonesia memiliki potensi yang besar sebagai negara penghasil produk pertanian. Salah satu sasaran pembangunan pertanian adalah menumbuhkembangkan sistem dan usaha pertanian yang berdaya saing tinggi sehingga dapat memberi kesejahteraan bagi pelaku usahatani. Tanaman yang banyak dibudidayakan oleh petani di Indonesia adalah padi. Padi yang menghasilkan beras merupakan bahan pangan pokok sangat dibutuhkan oleh masyarakat Indonesia. Oleh karena itu, padi sebagai penghasil beras harus mendapat perhatian baik mengenai lahan, benih, cara budidaya maupun pascapanen (Suparyono dan Setyono, 1997).

Tingkat konsumsi beras yang masih sangat tinggi disebabkan karena sebagian besar penduduk Indonesia masih beranggapan bahwa beras adalah bahan makanan pokok yang tidak dapat digantikan oleh bahan makanan pokok lainnya. Apabila kegiatan usahatani dikelola dengan baik dan benar seharusnya petani akan memiliki pendapatan yang cukup tinggi (Wijono, 2005). Menurut Badan Pusat Statistik Nusa Tenggara Timur mencatat produksi padi pada 2015 sebesar 948.088 ton Gabah Kering Giling (GKG) atau meningkat sebanyak 14,82 persen dari produksi 2014 yang tercatat sebesar 825.728 ton GKG. Peningkatan ini disebabkan oleh meningkatnya luas panen dan produktivitas masing-masing sebesar 7,90 persen dan 6,41 persen.

Pengembangan pertanian padi merupakan bagian dari pembangunan pertanian yang berperan penting dalam konteks pemenuhan kebutuhan pangan nasional khususnya di Nusa Tenggara Timur. Pembangunan pertanian nasional harus diawali dari lingkup terkecil dalam suatu wilayah. Berdasarkan potensi dan sumberdaya yang dimilikinya, suatu wilayah akan mengembangkan pertanian sebagai salah satu aspek pembangunan wilayahnya. Kabupaten Kupang merupakan daerah yang cukup dekat dengan Kota Kupang, terletak di Provinsi Nusa Tenggara Timur.

Petani sebagai mahkluk sosial yang tidak dapat hidup tanpa adanya bantuan dari orang lain, bantuan tersebut didapatkan melalui sebuah komunikasi yang terjalin antara manusia satu dengan lainnya. Dengan terjalinnya komunikasi, maka akan tercipta sebuah kehidupan yang saling melengkapi satu sama lain. Jadi komunikasi berlangsung apabila antara orang-orang yang terlibat terdapat kesamaan makna mengenai sesuatu hal yang dikomunikasikan. Jelasnya, jika seseorang mengerti tentang sesuatu yang dinyatakan orang lain kepadanya, maka komunikasi itu dapat berlangsung dan sebaliknya (Mulyana, 2005).

Berkaitan dengan pembangunan pertanian tersebut, perlu diciptakan komunikasi antara petani dan dinas pertanian dalam hal ini penyuluh pertanian sebagai komunikator dalam hal transfer teknologi dan pengetahuan. Hal ini dilakukan agar petani padi dapat menjalankan usahataninya 
dengan baik sehingga terjadi peningkatan hasil di setiap panennya. Menurut laporan akhir pengembangan iptek, bahwa permasalahan perkembangan dunia pertanian nasional yang berhubungan dengan sumberdaya manusia bidang pertanian selama ini salah satunya adalah lemahnya penguasaan teknis lapangan dan teori dari petani (Menristek, 2006).Menurut Dilla (2007) komunikasi sangat diperlukan dalam menunjang proses pembangunan karena komunikasi dapat digunakan untuk menjembatani arus informasi ide dan gagasan baru dari pemerintah kepada masyarakat atau sebaliknya.

Produktivitas petani padi di Desa Oesao masih rendah, hal ini karena sifat kegiatan yang mereka lakukan umumnya masih tradisional, skala usaha kecil, menggunakan teknologi sederhana dengan keterampilan yang dimiliki masih rendah dan usahatani yang masih bersifat sambilan. Oleh karena itu pemerintah Kabupaten Kupang memberikan fasilitas kepada petani, yakni dengan memberikan pembinaan untuk mendukung program peningkatan produksi hasil pertanian. Namun program pembangunan bidang pertanian masih jauh dari target.

Para petani dan pemerintah masih selalu berpendapat bahwa rendahnya produksi pertanian karena keterbatasan biaya. Tetapi sebagai peneliti melihat bahwa keterbatasan biaya yang dikeluhkan petani tidak menjadi suatu penghambat apabila masyarakat tani memiliki motivasi dalam menjalankan usaha pertaniannya dengan mengadopsi inovasi budidaya padi yang diberikan penyuluh pertanian selaku pembina. Pada proses transfer inovasi dan informasi yang dilakukan penyuluh ke petani terdapat hambatan-hambatan komunikasi yang dialami. Hal ini sama seperti kondisi pertanian yang ada di berbagai daerah, yaitu lemahnya sumberdaya manusia yang tersedia. Hal ini sesuai dengan pernyataan Susanto (1977) bahwa salah satu hambatan komunikasi di Indonesia adalah sumberdaya manusia. Kenyataan inilah yang menarik untuk diteliti sehingga dapat dianalisa hambatan-hambatan dan faktor-faktor yang mempengaruhinya di dalam proses komunikasi antara penyuluh dan petani padi di Desa Oesao, Kabupaten Kupang.

Penelitian ini bertujuan untuk mendeskripsikan faktor karakteristik individu dan aktivitas komunikasi, hambatan-hambatan komunikasi yang ada pada petani padiserta menganalisis hubungan antara faktor karakteristik individu petani dan aktivitas komunikasi dengan hambatan komunikasi yang dirasakan petani padi di Desa Oesao Kab. Kupang.

\section{METODE}

Penelitian ini bersifat deskriptif dan korelasional dengan menggunakan pendekatan kuantitatif. Pemilihan pendekatan kuantitatif digunakan untuk lebih memahami fakta sosial yang menjadi fokus penelitian (Singarimbun dan Effendi, 2008). Pendekatan kuantitatif dipilih oleh peneliti karena melihat deskripsi serta menjelaskan hubungan antar variabel secara mendalam, dengan unit analisis adalah petani tanaman padi sehingga dapat memperlihatkan hubungan yang jelas antar variabel. Terdapat dua variabel penelitian yang diamati yaitu karakteristik petani (X1), aktivitas komunikasi petani (X2), hambatan psikologi komunikasi antara pembina dan petani (Y). Hambatan komunikasi yang dirasakan petani dalam penelitian ini ditelaah berdasarkan perilaku berusahatani yang terdiri dari umur, jenis kelamin, pendidikan, pendapatan, pengalaman bertani, tingkat kekosmopolitan, tingkat pengetahuan tentang budidaya padi.

Penelitian dilakukan pada April-Agustus 2016 dengan mengambil lokasi di Desa Oesao, Kec. Kupang Timur, Kabupaten Kupang Provinsi Nusa Tenggara Timur. Lokasi penelitian dipilih secara purposive (sengaja) dengan mempertimbangkan bahwa desa ini memiliki areal pertanian padi yang relatif lebih luas dibandingkan dengan daerah lainnya dan membutuhkan suplai informasi mengenai teknologi pertanian. 
Unit analisis dalam penelitian ini adalah individu petani tanaman padi. Penentuan responden dalam penelitian ini menggunakan metode sensus dimana responden penelitian diambil dari keseluruhan populasi. Metode sensus digunakan karena mengingat jumlah petani hanya 75 orang. Jika jumlah anggota subjek dalam populasi hanya meliputi antara 100 hingga 150 orang dan dalam pengumpulan data peneliti menggunakan angket/kuesioner, sebaiknya subjek sejumlah itu diambil seluruhnya. Sehingga dapat dikatakan sebagai penelitian sensus (Arikunto, 1998).

Data yang digunakan dalam penelitian ini terdiri dari data primer dan data sekunder. Data primer yang diambil berasal dari peubah utama yang diteliti berupa faktor karakteristik petani, aktivitas komunikasi, hambatan psikologi komunikasi antarapembina dan petani yang diperoleh langsung lewat respondenmelalui wawancara kepada responden dan menggunakan kuesioner sertamelakukan wawancara terbuka dengan beberapa informan. Data sekunder diperoleh dari studi literatur, buku-buku, dan laporan-laporan.

Data penelitian dikumpulkan, dikategorisasikan, dianalisis dan disajikan secara deskriptif dalam bentuk rataan, persentase, dan tabel distribusi frekuensi. Analisis hubungan antar peubah menggunakan analisis statistik inferensial yaitu dengan menggunakankorelasi Tau Kendall yang pengolahan datanya menggunakan program SPSS (Statistical Package for the Social Sciences). Rumus korelasi Tau Kendall adalah sebagai berikut:

$$
\begin{aligned}
& \tau_{\tau=\frac{S}{1 / 2 N(N-1)}} \\
& \text { Ket: } \quad=\text { koefisien korelasi rank Tau } \\
& \begin{array}{ll}
\tau \quad \text { Kendall } N & =\text { jumlah data } \\
S \quad= & \text { jumlah selisih antara peringkat bagi Xi dan Yi }
\end{array}
\end{aligned}
$$

Alasan-alasan penggunaan korelasi Tau Kendall adalah 1) tidak ada anggapan bahwa skor yang dianalisis ditarik dari populasi dengan distribusi normal, 2) skor tidak eksak dalam pengertian semata-mata data berupa jenjang, dan 3) efisiensi cukup tinggi (Siegel, 1994).

\section{HASIL DAN PEMBAHASAN}

\section{Karakteristik Petani Padi di Desa Oesao}

Karateristik individu merupakan ciri-ciri yang dimiliki oleh individu yang ditampilkan melalui pola pikir, sikap dan tindakan terhadap lingkungan hidup, karakteristik petani padi di Desa Oesao yang memiliki keanekaragaman. Karakteristik individu petani dapat terbentuk oleh faktor biolagis, ataupun sosio psikologis, karakteristik individu merupakan salah satu faktor yang penting untuk diketahui jika ingin mengetahui perilaku dalam masyarakat. Karakteristik petani pada penelitian ini meliputi umur, pendidikan formal dan nonformal, pengalaman bertani, dan tingkat kekosmopolitan. Menurut Rogers (2003) karakteristik akan berpengaruh terhadap tingkat adopsi inovasi. Pada Tabel 1 dapat dilihat bahwa sebagian besar petani berusia produktif, yakni 90,67\% dan 94,67\% berjenis kelamin laki-laki. Petani di Desa Oesao sebagian besar tamatan SLTP sejumlah 29 orang atau $38,67 \%$, sebagian besar petani pernah mengikuti pelatihan budidaya padi. Terdapat 38 petani yang memiliki pengalaman berusahatani 5-13 tahun dan sebagian besar petani tidak mencari informasi teatang usahatani, hal ini terjadi karena petani tersebut sudah merasa memiliki pengalaman yang cukup dalam menjalankan kegiatan usatahaninya. 
Tabel 1. Persentase Petani Berdasarkan Jumlah dan Kategori Karakteristik Personal di Desa Oesao

\begin{tabular}{llrr}
\hline Karakteristik Petani & \multicolumn{1}{c}{ Kategori } & $\begin{array}{c}\text { Jumlah } \\
\text { (jiwa) }\end{array}$ & Persentase (\%) \\
& 17-64 tahun & 68 & 90,67 \\
& $>64$ tahun & 7 & 9,33 \\
\hline Umur & Perempuan & 4 & 5,33 \\
& Laki-laki & 71 & 94,67 \\
\hline Pendidikan formal & Tidak tamat SD & 6 & 8,00 \\
& Tamat SD & 12 & 16,00 \\
& Tamat SLTP & 29 & 38,67 \\
& Tamat SLTA & 26 & 34,67 \\
& Sarjana & 2 & 2,67 \\
\hline Pelatihan & Tidak pernah & 33 & 44,00 \\
budidaya padi & Pernah & 42 & 56,00 \\
\hline Pengalaman & Baru 5-13tahun & 38 & 50,33 \\
Usahatani padi & Cukup lama 14-26 tahun & 25 & 33,33 \\
& Lama $>$ 27 tahun & 12 & 16,00 \\
\hline Mencari informasi & Tidak pernah & 32 & 42,67 \\
& 1 kali & 10 & 13,33 \\
& 2 kali & 13 & 17,33 \\
& 3 kali & 20 & 26,67 \\
\hline
\end{tabular}

\section{Aktivitas Komunikasi}

Aktivitas komunikasi adalah penilaian petani padi terhadap kegiatan komunikasi yang dilakukan oleh petani dengan penyuluh untuk memenuhi kebutuhan informasi tentang budidaya tanaman padi. Terdapatlima indikator peubah aktivitas komunikasi yang diamati dalam penelitian ini, yaitu intensitas komunikasi, metode komunikasi, pencarian informasi, keterlibatan dalam kelompok dan arah komunikasi, lebih rinci dapat dilihat pada Tabel 2.

Budidaya padi merupakan salah satu peluang bisnis bagi petani sesuai potensi dan sumberdaya yang tersedia, karena komoditi padi dapat diusahakan dan dilakukan oleh sebagian besar rumah tangga petani baik untuk konsumsi keluarga maupun untuk dijual sebagai sumber pendapatan pokok. Kondisidi Kecamatan Kupang Timur menunjukkan bahwa lingkungan alam dengan geografisnya, dengan cuaca dan potensi lahan yang cukup mendukung bagi pengembangan usahatani padi.

Tabel 2. Skor Aktivitas Komunikasi Petani di Desa Oesao, 2016

\begin{tabular}{lcc}
\hline \multicolumn{1}{c}{ Aktivitas komunikasi } & Skor rata-rata & $\begin{array}{c}\text { Jenjang Aktivitas } \\
\text { Komunikasi }\end{array}$ \\
\hline Intensitas komunikasi & 2,39 & 4 \\
Metode komunikasi & 2,87 & 1 \\
Pencarian informasi & 2,10 & 5 \\
Keterlibatan dalam kelompok & 2,60 & 2 \\
Arah komunikasi & 2,53 & 3 \\
\hline Keterangan: $1,00-1.75=$ sangat rendah, $1,76-2,50=$ rendah, $2,51-3,25=$ sedangdan $3,26-4,00=$ tinggi
\end{tabular}


Tabel 2 menunjukkan bahwa jenjang aktivitas komunikasi menurut penilaian petani yang sering dilakukan berada pada skor rendah-sedang $(2,10-2,87)$, yaitu berturut-turut untuk metode komunikasi $(2,87)$, disusul keterlibatan dalam kelompok $(2,60)$, arah komunikasi $(2,53)$, intensitas komunikasi $(2,39)$ dan yang mendapat rataan skor terendah pencarian informasi $(2,10)$.

Tabel 3. Jumlah Dan Persen Petani Padi Menurut Aktivitas Komunikasi Berdasarkan Kategori di Desa Oesao.

\begin{tabular}{lcc}
\hline \multirow{2}{*}{ Kategori } & \multicolumn{2}{c}{ Perilaku berusahatani } \\
\cline { 2 - 3 } & Jumlah & Persen (\%) \\
\hline Tinggi & 4 & 5,33 \\
Sedang & 28 & 37,33 \\
Rendah & 43 & 57,33 \\
Sangat rendah & 0 & 0 \\
\hline
\end{tabular}

Berdasarkan Tabel 3, hasil penelitian menunjukkan 57,33\% atau sebagian besar petani padi belum menjalin komunikasi baik dengan penyuluh maupun sesama petani yang berhasil, belum memanfaatkan media sebagai sumber informasi dalam mengelola usahatani, belum memiliki kesadaran untuk berpartisipasi aktif dalam kegiatan kelompok tani yang ada di lingkungannya. Masih terdapat perbedaan pemahaman antara penyuluh dengan petani tentang pesan yang disampaikan dan kurangnya para petani berbagi pengalaman di antara sesama petani.

Selain itu, tidak ada petani padi yang aktivitas komunikasinya masuk ke dalam kategori sangat rendah.Petani padi yang memiliki aktivitas komunikasi sedang adalah petani yang suka mencari informasi tentang usahtani padi, selalu berkomunikasi dengan penyuluh dan petani padi lainnya.Aktivitas komunikasi petani dalam kategori sedang, hal ini disebabkan karena banyak petani yang ingin melaksanakan usahatani padi dengan baik tetapi terkendala dengan keadaan, tetapi mereka selalu melakukan usaha untuk memajukan usahatani dengan memperkaya diri dengan berbagai pengetahuan tentang usahatani padi sehingga mereka bisa meningkatkan produksi dan pendapatan mereka.

\section{Hambatan-Hambatan Komunikasi}

Penelitian ini meminta petani untuk memberikan pernyataan mengenai hambatan-hambatan komunikasi yang dirasakan. Untuk mengetahui hambatan-hambatan komunikasi yang dirasakan dihitung dengan nilai rataan skor terbobot. Faktor kendala yang mendapat nilai rataan skor terbobot tertinggi adalah faktor kendala dalam komunikasi yang paling dirasakan oleh petani tanaman padi di Desa Oesao. Hambatan-hambatan komunikasi yang dirasakan petani secara lengkap dapat dilihat pada Tabel 4.

Hambatan komunikasi yang paling dirasakan oleh petani adalah keakraban $(2,76)$ setelah itu perhatian (2,61), hambatan komunikasi ketiga yang dirasakan petani adalah prasangka $(2,25)$, perbedaan harapan berada pada urutan keempat $(2,12)$ dan terakhir hambatan komunikasi yang tidak begitu berpengaruh dengan hambatan komunikasi yaitu perbedaan kebutuhan $(1,82)$. Berikut uraian tentang hambatan-hambatan komunikasi yang dirasakan oleh para petani padi yang disusun berdasarkan urutan jenjangnya. 
Tabel 4. Hambatan-Hambatan Komunikasi Yang Dirasakan Petani Padi Di Desa Oesao, Tahun 2016

\begin{tabular}{lcc}
\hline Hambatan Komunikasi & Rataan Skor & $\begin{array}{c}\text { Jenjang hambatan } \\
\text { komunikasi }\end{array}$ \\
\hline Perbedaan harapan & 2,12 & 4 \\
Prasangka & 2,25 & 3 \\
Perbedaan kebutuhan & 1,82 & 5 \\
Perhatian & 2,61 & 2 \\
Keakraban & 2,76 & 1 \\
\hline Keterangan: $1,00-1,75=$ sangat rendah, $1,76-2,50=$ rendah, $2,51-3,25=$ sedang dan $3,26-4,00=$ tinggi
\end{tabular}

Umur, pendidikan, dan pendapatan tidak berhubungan nyata dengan hambatan komunikasi (perbedaan harapan, prasangka, perbedaan kebutuhan, perhatian, dan keakraban). Artinya umur, pendidikan, dan pendapatan tidak berpengaruh terhadap besar kecilnya hambatan komunikasi yang dialami antara petani dan penyuluh pertanian. Hal ini karena kultur masyarakat yang ada di Desa Oesao bersifat egaliter (sama), dimana mereka memiliki tata cara dan kebiasaan dalam bertani yang sama dan mempunyai kepentingan yang sama dalam melalukan usahatani padi, yaitu untuk meningkatkan produksi usahatani padi.

Umur dan pendidikan cenderung tidak berhubungan nyata negatif dengan hambatan komunikasi. Hal ini karena berdasarkan data penelitian, umur dan pendidikan tidak berada pada kategori tinggi sehingga tidak mempengaruhi rendahnya hambatan komunikasi yang dirasakan petani. Hubungan karakteristik individu petani dengan hambatan komunikasi dapat dilihat lebih jelas pada Tabel 5.

Tabel 5. Hubungan Antara Karakteristik Individu Petani dengan Hambatan-Hambatan Komunikasi

\begin{tabular}{|c|c|c|c|c|c|}
\hline \multirow{2}{*}{$\begin{array}{l}\text { Karakteristik } \\
\text { Individu Petani }\end{array}$} & \multicolumn{5}{|c|}{ Hambatan-hambatan Komunikasi ( $\mathrm{T})$} \\
\hline & $\begin{array}{l}\text { Perbedaan } \\
\text { Harapan }\end{array}$ & Prasangka & $\begin{array}{l}\text { Perbedaan } \\
\text { kebutuhan }\end{array}$ & Perhatian & Keakraban \\
\hline Umur & $-0,008$ & $-0,011$ & 0,119 & $-0,048$ & $-0,028$ \\
\hline Pendidikan & 0,009 & $-0,145$ & $-0,045$ & $-0,035$ & $-0,097$ \\
\hline Pendapatan & 0,018 & 0,162 & 0,062 & 0,063 & 0,048 \\
\hline Pengalaman & 0,048 & $0,246^{* *}$ & $0,198^{*}$ & $0,185^{* *}$ & $0,270^{* *}$ \\
\hline Kekosmopolitan & $-0,076$ & $-0,232^{* *}$ & $-0,365^{*}$ & $-0,346^{* *}$ & $-0,410^{*}$ \\
\hline $\begin{array}{l}\text { Tingkat } \\
\text { pengetahuan }\end{array}$ & $-0,320^{* *}$ & $-0,217^{* *}$ & $-0,542^{*}$ & $-0,497^{* *}$ & $-0,545^{*}$ \\
\hline
\end{tabular}

Hasil uji korelasi Tau Kendall antara pengalaman dan hambatan komunikasi pada variabel perbedaan harapan menggambarkan tidak adanya hubungan nyata. Hal ini dapat diartikan bahwa pengalaman tidak memiliki pengaruh terhadap hambatan komunikasi yang dirasakan oleh para petani padi. Sementara pengalaman berhubungan sangat nyata $(p<0,01)$ positif dengan hambatan komunikasi (prasangka, perhatian dan keakraban). Artinya semakin tinggi tingkat pengalaman 
seorang petani padi maka hambatan komunikasi (prasangka, perhatian dan keakraban) yang dirasakan petani akan semakin tinggi juga. Hal ini karena petani yang sudah berpengalaman, rata-rata telah berumur tua dan telah mengenal budidaya padi secara turun menurun sehingga bagi mereka informasi yang diberikan oleh para penyuluh bukanlah hal yang baru buat mereka. Di sisi lain petani yang telah berpengalaman merasa sudah sering mendapatkan penyuluhan dari instansi terkait tapi hanya sebatas pemberitahuan sehingga mereka menganggap bahwa penyuluh datang ke tempat mereka hanya untuk melaksanakan program kerja penyuluh saja.

Petani padi yang sudah berusia tua perlu diberikan perhatian yang lebih dari penyuluh pertanian. Penyuluh diharapkan memberikan tanggapan yang cepat pada pertanyaan-pertanyaan yang mereka ajukan dan diberikan tanggapan dengan bentuk kerja nyata. Para petani akan mengalami kekecewaan jika tanggapan yang diberikan tidak sesuai dengan harapan mereka. Petani yang lebih berpengalaman juga akan sulit untuk akrab dengan penyuluh karena adanya prasangka dan kurangnya perhatian yang diberikan penyuluh. Hal ini sesuai dengan pendapat responden yang berumur 55 tahun menyatakan bahwa:

"Kami ini sudah berumur, sudah lama melakukan ini usaha, mulai dari kami masih kecil, masih membantu orang tua. Ini kerjaan sudah kami lakukan berulang-ulang, jadi sudah biasa. Bapak Ibu penyuluh juga datang jelaskan hal yang hasilnya nanti sama. Mereka datang dengan biaya kantor, itu program kantor".

Hasil analisis yang dilakukan menunjukkan bahwa pengalaman juga berhubungan nyata $(p<0,05)$ positif dengan hambatan komunikasi pada variabel perbedaan kebutuhan. Ini menunjukkan bahwa semakin lama pengalaman petani dalam berusahatani padi maka makin tinggi hambatan komunikasi (Perbedaan kebutuhan) yang dirasakan. Pengalaman berusahatani yang lama membuat petani telah memiliki kebiasaan dengan kegiatan usahataninya sehingga sulit untuk menerima informasi ataupun inovasi baru yang diberikan oleh penyuluh. Sementara petani sendiri akan lebih tertarik jika diberikan materi yang sesuai dengan kebutuhannya. Hal ini sesuai dengan teori (Djasmin dalam Suprapto \& Fahrianoor, 2004) yang menyatakan salah satu faktor psikologis hambatan dalam proses belajar petani adalah petani baru mau belajar jika materi sesuai dengan kebutuhannya.

Kekosmopolitan berhubungan sangat nyata $(p<0,01)$ negatif dengan hambatan komunikasi (prasangka, perbedaan kebutuhan, perhatian dan keakraban). Artinya semakin tinggi tingkat kekosmopolitan maka hambatan komunikasi (prasangka, perbedaan kebutuhan, perhatian dan keakraban) yang dirasakan petani semakin rendah. Seringnya petani berhubungan dengan lingkungan diluar lingkungannya membuat petani lebih terbuka wawasannya. Semakin terbuka seorang petani terhadap dunia luar dan bersedia menerima ide-ide baru dalam pengembangan usahatani padi maka petani tersebut akan memiliki pengetahuan yang lebih banyak. Petani dengan mudah dapat menerima orang luar (penyuluh) tanpa ada prasangka dan dapat berkomunikasi dengan baik sehingga tidak merasakan adanya hambatan komunikasi.

Pada penelitian ini, kekosmopolitan tidak berpengaruh terhadap hambatan komunikasi pada variabel perbedaan harapan. Berdasarkan hasil pengamatan di lapangan diketahui bahwa adanya hambatan komunikasi dalam hal perbedaan harapan merupakan hal yang sulit untuk dihilangkan dari petani karena kebiasaan masyarakat yang masih sangat terikat dengan budaya/kebiasaan turun-menurun petani dalam menjalankan usahatani. Informasi yang diberikan penyuluh banyak yang tidak sesuai dengan harapan petani dalam hal budidaya tanaman padi sehingga walaupun petani mengerti dengan materi yang diberikan tetapi petani belum mau menerapkannya dalam usahataninya. Hal ini sesuai dengan pernyataan responden lain yakni: 
"saya sudah lama menanam padi, saya sudah menanam jenis padi yang sudah biasa saya tanam sehingga saya tidak terlalu butuh informasi dari mereka apalagi jika tidak sesuai dan belum ada buktinya. Mereka datang meminta saya untuk menanam bibit unggul tapi mereka juga tidak membawa bibit yang banyak, jika mau beli harus pesan dulu dan waktunya lama."

Hal yang terjadi di lapangan, kekosmopolitan petani rata-rata rendah sehingga hambatan komunikasi yang dirasakan oleh petanicukup tinggi. Hal ini sebaiknya menjadi perhatian bagi para penyuluh sehingga dapat membuat strategi dalam memberikan materi budidaya tanaman padi dengan lebih baik dan menarik agar dapat di terima oleh petani yang ada di Desa Oesao.

Hasil analisis menunjukkan bahwa terdapat hubungan sangat nyata $(p<0,01)$ negatif antara tingkat pengetahuan dengan hambatan komunikasi (Perbedaan harapan, prasangka, perbedaan kebutuhan, perhatian, dan keakraban). Artinya semakin tinggi tingkat pengetahuan petani maka semakin rendah hambatan yang dirasakan petani. Dengan bertambahnya pengetahuan petani maka kebutuhan petani akan pengetahuan pun bertambah sehingga membutuhkan informasi-informasi yang diberikan oleh penyuluh, hal inilah yang membuat hambatan komunikasi yang dirasakan petani menurun. Pengetahuan yang petani dapat dari penyuluh atau dari sumber lain mereka terapkan dalam usahatani padi.

Berdasarkan uraian hasil analisis tersebut maka secara umum hipotesis pertama yang menyatakan terdapat hubungan nyata antara faktor karakteristik individu petani dengan hambatanhambatan komunikasi yang dirasakan petani dalam penyuluhan budidaya padi potong di Desa Oesao diterima untuk pengalaman, kekosmopolitan dan tingkat pengetahuan.

\section{Hubungan Aktivitas Komunikasi dan Hambatan Komunikasi yang dirasakanPetani dalam Penyuluhan budidaya tanaman Padi}

Intensitas komunikasi tidak berhubungan nyata dengan hambatan komunikasi (perbedaan harapan dan prasangka), artinya sering atau tidaknya petani bertemu dengan penyuluh tidak ada pengaruhnya terhadap hambatan komunikasi yang dirasakan petani. Hal ini karena dari awal harapan petani sudah berbeda dengan penyuluh, dan rasa kecewa yang biasa petani rasakan prasangka yang dirasakan oleh petani sulit untuk dihilangkan. Hubungan antara aktivitas komunikasi dengan hambatan-hambatan komunikasi secara lengkap dapat dilihat pada Tabel 6.

Hasil uji analisis korelasi Tau Kendal pada intensitas komunikasi berhubungan sangat nyata $(p<0,01)$ negatif dengan hambatan komunikasi (perbedaan kebutuhan, perhatian dan keakraban). Hal ini dapat diartikan bahwa semakin tinggi intensitas komunikasi yang dilakukan oleh petani maka semakin rendah hambatan komunikasi (perbedaan kebutuhan, perhatian dan keakraban) yang akan dirasakan petani.

Seringnya petani bertemu dengan penyuluh akan mempengaruhi pola pikir petani mengenai usahatani padi yang dilakukan sehingga yang awalnya petani merasa sudah mengetahui semua informasi sehingga tidak lagi membutuhkan informasi menjadi tertarik dan merasa membutuhkan informasi tersebut. Seringnya petani bertemu penyuluh juga membuka kesempatan pada penyuluh untuk dapat memberikan perhatiannya ke usahatani yang dijalankan oleh para petani. Petani dan penyuluh bisa berdiskusi mengenai masalah petanian yang sedang terjadi, tentang kekecewaan yang sering dirasakan dan para penyuluh bisa memberikan solusi dengancepat dan tepat sehingga terjalin hubungan yang baik dan keakraban antara penyuluh dan petani padi. Hal ini dapat memperkecil atau mengurangi hambatan komunikasi yang terjadi atau bahkan jika terjalin hubungan yang baik dapat menghilangkan hambatan komunikasi tersebut. 
Tabel 6. Hubungan Antara Aktivitas Komunikasi dengan Hambatan-Hambatan Komunikasi

\begin{tabular}{lccccc}
\hline \multirow{2}{*}{ Aktisivitas komunikasi } & \multicolumn{5}{c}{ Hambatan-Hambatan Komunikasi $(\tau)$} \\
\cline { 2 - 6 } & $\begin{array}{c}\text { Perbedaan } \\
\text { harapan }\end{array}$ & Prasangka & $\begin{array}{c}\text { Perbedaan } \\
\text { kebutuhan }\end{array}$ & Perhatian & Keakraban \\
\hline Intensitas komunikasi & $-0,121$ & $-0,119$ & $-0,376^{* *}$ & $-0,483^{* *}$ & $-0,329^{* *}$ \\
Metode komunikasi & $-0,291^{* *}$ & $-0,275^{* *}$ & $-0,753^{* *}$ & $-0,662^{* *}$ & $-0,687^{* *}$ \\
Pencarian informasi & $-0,042$ & $-0,324^{* *}$ & $-0,414^{* *}$ & $-0,413^{* *}$ & $-0,419^{* *}$ \\
Keterlibatan dalam kelompok & $-0,172^{* *}$ & $-0,319^{* *}$ & $-0,511^{* *}$ & $-0,481^{* *}$ & $-0,495^{* *}$ \\
Arah komunikasi & $-0,341^{* *}$ & $-0,111$ & $-0,334^{* *}$ & $-0,361^{* *}$ & $-0,379$ \\
\hline Ketyyyyyy
\end{tabular}

Keterangan: * berhubungan nyata $(\mathrm{p}<0,05) \mathrm{\tau}=$ korelasi Tau Kendall ** berhubungan sangat nyata $(\mathrm{p}<0,01)$

Metode komunikasi berhubungan sangat nyata $(p<0,01)$ negatif dengan hambatan komunikasi (perbedaan harapan, prasangka, perbedaan kebutuhan, perhatian dan keakraban). Artinya semakin sering intensitas petani dalam merasakan metode komunikasi yang digunakan penyuluh maka semakin rendah hambatan komunikasi (perbedaan harapan,prasangka, perbedaan kebutuhan, perhatian dan keakraban) yang dirasakan petani. Metode komunikasi merupakan hal yang sangat penting dalam penyampaian informasi, karena penggunaan metode komunikasi yang salah akan mengakibatkan komunikasi yang terjadi tidak efektif, sehingga pesan yang disampaikan oleh penyuluh tidak diterima dengan baik oleh petani.

Hasil wawancara di lapangan menunjukkan bahwa petani lebih senang apabilametode komunikasi yang digunakan adalah kunjungan langsung yaitu penyuluh mengunjungi ke sawah atau lingkungan para petani, sehingga petani dapat bertanya secara langsung mengenai permasalahan usahataninya saat itu juga dan tidak merasa canggung dengan penyuluh. Selain hal itu metode kunjungan tersebut dapat juga mendekatkan hubungan antara penyuluhdan petani sehingga hambatan komunikasi seperti perbedaan harapan, prasangka, perbedaan kebutuhan, perhatian dan keakraban penyuluh dan petani dapat dikurangi. Hal ini sesuai dengan pernyataan responden yakni: "Kami sebagai petani lebih menyukai jika para penyuluh itu datang langsung melihat kami di sawah tempat kami menanam padi, jangan mengundang kami ke kantor penyuluh. Karena para penyuluh bisa langsung melihat keadaan sawah dan tanaman dan kami juga para petani lebih leluasa bertanya tentang masalah-masalah yang kami hadapi di sawah"

Pencarian informasi tidak berhubungan nyata dengan perbedaan harapan, hal ini dapat diartikan bahwa tinggiatau rendahnya pencarian informasi petanitidak mempengaruhi hambatan komunikasiyang mereka rasakan. Tetapi pencarian informasi berhubungan sangat nyata negatif dengan hambatan komunikasi (prasangka, perbedaan kebutuhan, perhatian dan keakraban) yang artinya semakin tinggi tingkat pencarian informasi yang dilakukan makasemakin rendah hambatan komunikasi (prasangka, perbedaan kebutuhan, perhatian dan keakraban) yang dirasakan petani. Keterlibatan dalam kelompok berhubungan nyata $(p<0,05)$ negatif dengan hambatan komunikasi pada variabel perbedaan harapan. Artinya semakin tinggi keterlibatan petani dalam kelompok maka hambatan komunikasi yang dirasakan akan semakin rendah. Hal ini karena petani yang selalu hadir, aktif dalam berdiskusi, bertanya dan memberikan saran telah terdedah oleh informasi yang diterimanya dari penyuluh dan petani lain yang ada dalam kelompok.

Keterlibatan dalam kelompok berhubungan sangat nyata $(p<0,01)$ negatif dengan hambatan komunikasi (prasangka, perbedaan kebutuhan, perhatian dan keakraban), artinya semakin tinggi keterlibatan petani dalam kelompok maka semakin rendah hambatan komunikasi (prasangka, perbedaan kebutuhan, perhatian dan keakraban) yang dirasakan petani. 
Arah komunikasi berhubungan sangat nyata $(p<0,01)$ negatif dengan hambatan komunikasi (perbedaan harapan, perbedaan kebutuhan dan perhatian). Artinya semakin baik arah komunikasi yang digunakan penyuluh maka hambatan komunikasi (perbedaan harapan, perbedaan kebutuhan dan perhatian) yang dirasakan petani semakin rendah. Komunikasi dapat berjalan efektif jika terdapat kesamaan makna antara komunikator dan komunikan, pemilihan dialog (komunikasi dua arah) oleh penyuluh merupakan cara yang tepat. Hal ini akan membuat petani merasa pendapatnya didengar dan keputusan-keputusan yang diambil sesuai dengan yang petani inginkan.

Arah komunikasi tidak berhubungan nyata dengan hambatan komunikasi (prasangka, keakraban), artinya tidak ada hubungan antara arah komunikasi yang digunakan penyuluh dengan hambatan komunikasi (prasangka dan keakraban) yang dirasakan petani. Berdasarkan hasil analisis, hipotesis kedua yang menyatakan terdapat hubungan nyata antara aktivitas komunikasi dengan hambatan-hambatan komunikasi yang dirasakan petani dalam pembinaan budidaya padi di Desa Oesao diterima artinya terdapat hubungan nyata antara aktivitas komunikasi dengan hambatan-hambatan komunikasi yang dirasakan petani dalam pembinaan budidaya tanaman padi di Desa Oesao.

\section{SIMPULAN DAN SARAN}

Berdasarkan karakteristik petani, sebagian besar $90,7 \%$ petani berusia produktif, yakni $90,67 \%$ dan $94,7 \%$ adalah laki-laki, 38,7\% tamatan SLTP, 56\% petani pernah mengikuti pelatihan budidaya padi dan $50 \%$ petani yang memiliki pengalaman berusahatani 5-13 tahun. Hambatan komunikasi yang paling dirasakan petani adalah pada faktor perhatian dan keakraban, disusul dengan faktor prasangka, perbedaan harapan dan perbedaan kebutuhan. Pengalaman petani berhubungan sangat nyata pada faktor hambatan prasangka,perhatian dan keakraban serta berhubungan nyata dengan hambatan komunikasi faktor perbedaan kebutuhan. Karakteristik kekosmopolitan petani berhubungan sangat nyata negatif dengan faktor hambatan-hambatan komunikasi pada prasangka, perbedaan kebutuhan, perhatian dan keakraban. Karakteristik tingkat pengetahuan petani berhubungan sangat nyata negatif dengan seluruh faktor hambatan-hambatan komunikasi yang dirasakan petani padi di Desa Oesao. Aktivitas komunikasi secara umum berhubungan nyata dan sangat nyata dengan hambatan-hambatan komunikasi yang dirasakan petani padi di Desa Oesao.

Berdasarkan hasil penelitian maka dapat disarankan hal-hal sebagai berikut. Perlu adanya kegiatan pelatihan motivasi untuk petani, agar petani memahami usahatani yang mereka lakukan sehingga memiliki nilai ekonomi sehingga semangat petani dapat lebih ditingkatkan dalam pencarian informasi budidaya tanaman padi. Selain itu, juga perlu adanya peningkatan frekuensi pertemuan antara penyuluh dan petani, tidak hanya pada kegiatan kelompok tani tetapi sebaiknya diadakan kegiatan sosial yang ada dilingkungan petani, agar petani merasa dekat dengan penyuluh sehingga hambatan komunikasi yang disebabkan faktor keakraban dapat dikurangi.

\section{REFERENSI}

Arikunto. (1998). Prosedur Penelitian: Suatu Pendekatan Praktek. Jakarta: Rineka Cipta.

Dilla, S. (2007). Komunikasi Pembangunan: Pendekatan Terpadu. Bandung: Simbiosa Ekatama Media.

Menristek. (2006). Pengemnangan IPTEK untuk Peningkatan Daya Saing Produk Pangan Hasil Peternakan. Draf Laporan Kementerian Negara Riset dan Teknologi Bekerjasama dengan Universitas Sriwijaya.Palembang: Universitas Sriwijaya. 
Mulyana, D. (2005). IImu Komunikasi: Suatu Pengantar. Bandung: Remaja Rosdakarya.

Rogers. (2003). Diffusion of innovations (5th ed.) New York: The Free Press.

Siegel. (1994). Statistik Non Parametrik. Jakarta: Gramedia.

Singarimbun \& Effendi. A. (2008). Metode Penelitian Survai. Jakarta: Pustaka LP3ES Indonesia.

Suparyono \& Setyono, A. (1997). Mengatasi Permasalahan Budidaya Padi. Jakarta: Penebar Swadaya.

Suprapto \& Fahrianoor. (2004). Komunikasi Penyuluhan dalam Teori dan Praktek. Yogyakarta: Arti Bumi Intaran.

Susanto, AS. (1977). Problems of Communication Planning in Indonesia. Di dalam Rahim SA, Middleton J, editor. Perspectives in Communication Policy andPlanning. Ed ke-3. Hawaii: East-West Center, East-West CommunicationInstitute.

Wijono Wiloejo. (2005). Mengungkap sumber-Sumber Pertumbuhan Ekonomi Indonesia dalam Lima Tahun Terakhir. Jurnal Manajemen dan Fiskal, No V. 